\title{
ПІДХОДИ ЩОДО ФОРМУВАННЯ КОНКУРЕНТНОГО ПОТЕНЦІАЛУ ТОРГОВИХ МАРОК НА ПРИКЛАДІ ПРОТИВИРАЗКОВИХ ПРЕПАРАТІВ
}

\author{
(ㄱ. В. Волкова \\ Національний фармацевтичний університет, Харків
}

\begin{abstract}
Резюме: за результатами аналізу узагальнено основні підходи щодо визначення понять «конкурентоспроможність» та «конкурентний потенціал», а також систематизовано показники оцінки конкурентоспроможності товарів за соціальною, виробничою та маркетинговою складовими.

Встановлено, що на формування конкурентного потенціалу торгових марок впливають раціональні та емоційні критерії, оцінка яких передбачає проведення комплексного маркетингового і фармакоекономічного аналізу лікарських препаратів. На прикладі торгових марок групи противиразкових препаратів обґрунтовано розроблену модель формування конкурентного потенціалу з урахуванням існуючого рівня розвитку та факторів впливу на формування перспективного потенціалу.
\end{abstract}

Ключові слова: конкурентний потенціал, торгові марки, противиразкові лікарські препарати.

Вступ. За умов розвитку доказової медицини та фармації, впровадження формулярної системи і страхових переліків лікарських препаратів (ЛП) у систему фармацевтичного забезпечення постає необхідність виокремити вітчизняні препарати серед великої кількості існуючих на українському ринку, що надасть можливість забезпечити населення повною фармацевтичною інформацією і ефективною, якісною та доступною медичною допомогою.

У сучасній маркетинговій практиці одним 3 основних способів ідентифікації товарів на ринку відносно конкурентів $є$ створення торгових марок (ТМ) [1-3]. Відповідно стратегічний підхід до визначення конкурентних переваг ТМ ЛП з маркетингової та фармакоекономічної точок зору на основі використання теоретичних та методологічних розробок в сфері аналізу конкурентної боротьби на фармацевтичному ринку стає однією з передумов розвитку їх потенціалу. За таких умов стає необхідним визначення чинників формування конкурентного потенціалу та їх впливу на перспективність розвитку ТМ ЛП у ринковому сегменті, що дозволить розробити належну стратегію розвитку для вітчизняних виробників та забезпечити доступність ліків для населення.

Метою нашого дослідження стало узагальнення напрямків оцінки конкурентоспроможності товарів і розробка комплексного підходу щодо формування конкурентного потенціалу ТМ лП на прикладі противиразкових.

Методи дослідження. У ході дослідження нами використано методи мета-аналізу, порівняльного, історичного, логічного і системно- аналітичного аналізу, а також дані власних попередніх досліджень.

Результати й обговорення. Сьогодні науковцями-маркетологами виокремлюють різнопланові підходи визначення поняття «конкурентоспроможність», враховуючи особливості даної категорії, зокрема, їі багаторівневість, багатоаспектність і багатофакторність [4-6]. За узагальненим визначенням групи науковців [5, 7], конкурентоспроможність - це більш високе порівняно з товарами-замінниками співвідношення сукупності якісних характеристик товару і витрат на його придбання та споживання при їх відповідності вимогам ринку або його певного сегменту. Також має місце визначення даної категорії з урахуванням соціальних, економічних, маркетингових, виробничих і комерційних аспектів як ринкової властивості товару, що визначає його потребу на ринку, спроможність приносити прибуток виробникам та торговим підприємствам [8, 9].

За результатами аналізу даних літературних джерел щодо підходів в оцінці конкурентоспроможності товару встановлено, що пропонується використовувати критерії кількісної та якісної характеристик товару, які розподіляються залежно від основних напрямків діяльності підприємства [5, 8-10]. Нами узагальнено показники, за допомогою яких проводиться аналіз конкурентоспроможності товару, та систематизовано їх залежно від площини ринкового середовища (рис. 1).

Фармацевтичні товари, зокрема ЛП, мають особливості щодо визначення переліку параметрів оцінки конкурентоспроможності. Так, у

ISSN 2312-0967. Pharmaceutical review. 2015. № 1 
Фармацевтичний менеджмент, маркетинг та логістика

Pharmaceutical management, marketing and logistics

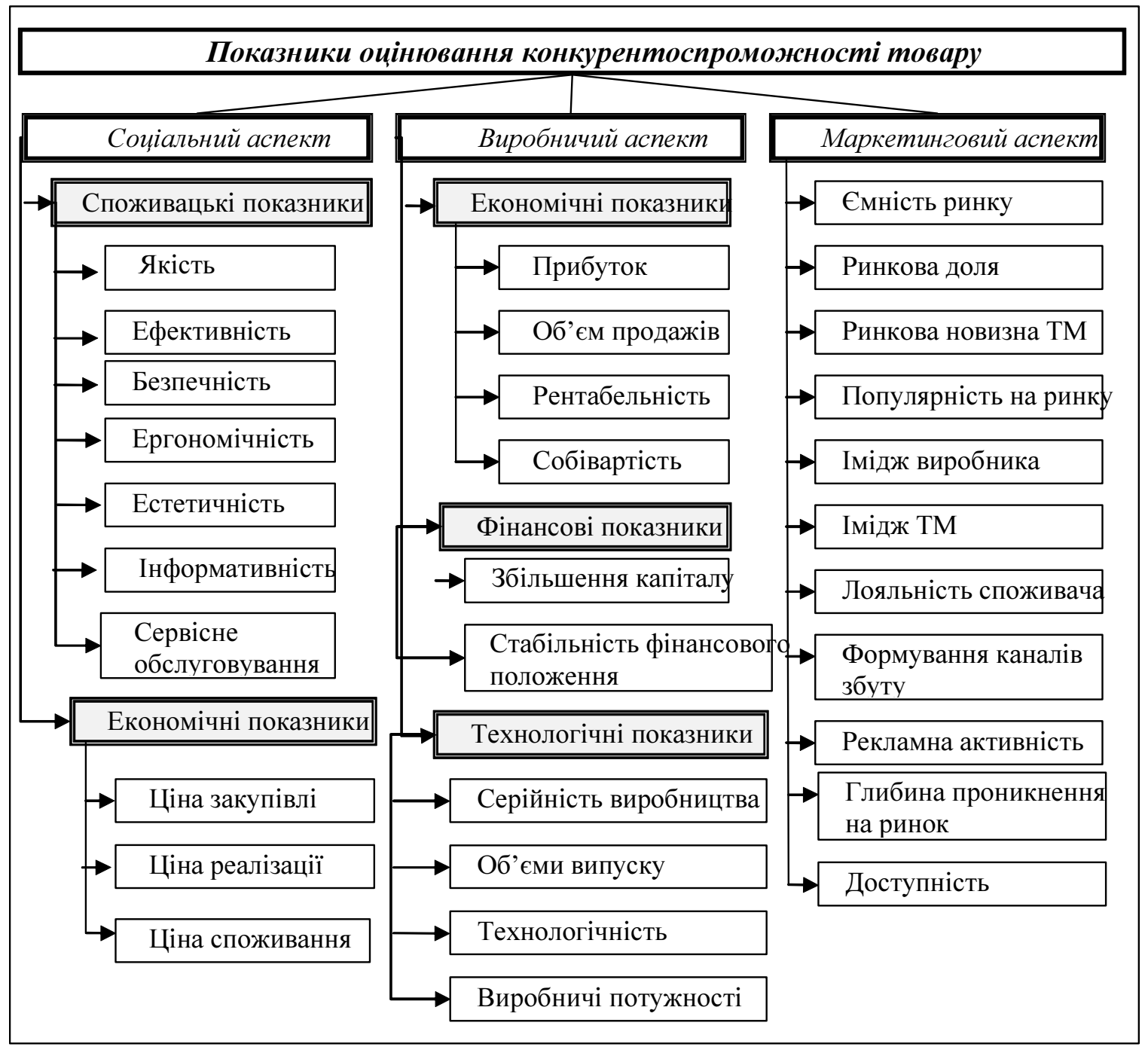

Рис. 1. Узагальнені показники конкурентоспроможності товару.

соціальному аспекті, що передбачає врахування інтересів та вигоди кінцевих споживачів, для ЛП виокремлюють категорію фармакотерапевтичних параметрів (ефективність, безпечність, зручність дозування та застосування, фармакокінетичні, фармакодинамічні, фармакоекономічні показники тощо). Виробничий аспект оцінки конкурентоспроможності, окрім зазначених показників, для ЛП повинен враховувати структуру товарного асортименту фармацевтичних підприємств, наявність ТМ, новизну технології виробництва ліків та відповідність міжнародним стандартам. Інтереси і вигоди торгових підприємств, до яких на фармацевтичному ринку відносять оптові фірми, аптечні мережі, аптеки та їх підрозділи, враховує маркетинговий аспект конкурентоспроможності ЛП [11, 12].

Останнім часом у багатьох сферах діяльності поняття «конкурентоспроможність» використо- вується у призмі конкурентного потенціалу. Так, науковці та маркетологи-практики оцінюють потенціал не лише як кількість ресурсів, але і як включену в них можливість розвитку системи в заданому руслі; як симбіоз кількісних показників та якісних методів й моделей [4, 8]. Конкурентний потенціал ТМ, в свою чергу, визначають як сукупність можливостей підприємства використовувати функціональні та емоційні властивості TM в системі управління ключовими чинниками успіху з метою посилення переваг у конкурентній боротьбі, закріплення ринкової позиції, формування стійкої переваги з боку споживачів, отримання можливостей для подальшого перетворення в бренд $[1,7,12]$.

Враховуючи, що фармацевтична доступність ліків залежить від комплексу чинників соціального, виробничого і торговельного характеру, обов'язковою складовою оцінки конкурентно-

ISSN 2312-0967. Фармацевтичний часопис. 2015. № 1 
Фармацевтичний менеджмент, маркетинг та логістика

Pharmaceutical management, marketing and logistics

го потенціалу ЛП повинен бути багатокритеріальний аналіз перспективності розвитку сегментів і окремих ТМ препаратів. Так, встановлено, що оцінка можливості розвитку будь-якого ЛП не можлива без комплексного аналізу поточної позиції у конкурентному середовищі, при цьому формування ключових груп чинників впливу на конкурентоспроможність ТМ відбувається на рівні споживача (соціальні фактори), на рівні виробника та його ринкового становища (виробничо-маркетингові) та на рівні безпосередньо самого ринку (торговельно-маркетингові чинники) [11].

Наступний етап нашого дослідження передбачав розробку підходів щодо формування конкурентного потенціалу ЛП на прикладі сегменту противиразкових засобів (ПВЛП).

Велика чисельність пацієнтів 3 хворобами органів травлення серед населення України при одночасному розвитку фармацевтичного виробництва та зростанні вітчизняного ринку ЛП створює потребу для проведення аналізу ринку ПВЛП та визначення впливу різних факторів на конкурентний потенціал вітчизняних ТМ препаратів даної групи. За результатами попередніх досліджень встановлено, що даний сегмент характеризуються досить відмінним тенденціями розвитку, що перш за все спричинено впливом факторів загального конкурентного середовища ринку й особливостями ЛП підгруп сегмента $[12,13]$.

Базуючись на проведеному аналізі, нами запропоновано модель формування конкурентного потенціалу ТМ ЛП на прикладі групи противиразкової дії з урахуванням раціональних та емоційних факторів зовнішнього і внутрішнього впливу (рис. 2).

Оцінку наявної конкурентної позиції рекомендовано починати 3 визначення раціональних критеріїв формування потенціалу ТМ ПВлП, зокрема, з оцінки соціальних показників зовнішнього середовища (демографічної структури та рівня захворюваності на виразкову хворобу та відповідно рівня споживання ПВЛП) та внутрішнього середовища (фармакоекономічних показників ефективності лікування виразкової хвороби).

Наступним етапом нами пропонується проводити оцінку виробничо-маркетингових критеріїв шляхом аналізу конкурентоспроможності виробника згідно з переліком зазначених критеріїв.

Визначення торговельно-маркетингових складових формування конкурентного потенціалу, на нашу думку, доцільно проводити шляхом сегментування досліджуваної групи ПВлП на препарати аналоги та синоніми з подальшою оцінкою їх конкурентної позиції у сегменті. На підставі отриманих даних рекомендовано визначати наявний конкурентний потенціал ТМ.

Наступним етапом пропонується проводити визначення емоційної складової з точки зору впливу внутрішніх факторів конкурентного потенціалу ТМ ПВЛП, що здійснюється шляхом експертної оцінки рівня довіри до виробника препаратів та окремих ТМ серед лікарів та провізорів.

На заключному етапі передбачено визначення чинників впливу на перспективність розвитку сегмента або ТМ та їх вагомості, що встановлюється опитуванням профільних фахівців. Шляхом поєднання визначеного наявного конкурентного потенціалу ТМ ЛП та факторів впливу на перспективний проводиться оцінка перспективного конкурентного потенціалу ПВЛП.

Таким чином, використання всебічної оцінки конкурентного потенціалу ТМ ЛП відповідно запропонованої моделі формування поточного та перспективного потенціалу з урахуванням факторів соціальної складової, фармакоекономічних показників ефективності лікування, особливостей ринкового розвитку виробників та ТМ і уподобань споживачів є підґрунтям для розробки товарної політики фармацевтичними виробничими і торговими підприємствами.

Висновки. Згідно з результатами аналізу літературних джерел проведено узагальнення показників конкурентоспроможності та здійснено їх групування за соціальним, виробничим та маркетинговим аспектами, які передбачають проведення оцінки споживацьких, економічних, фінансових, технологічних параметрів.

3 використанням маркетингових та фармакоекономічних підходів до визначення конкурентного потенціалу ТМ ЛП на прикладі групи противиразкової дії обґрунтовано модель формування конкурентного потенціалу препаратів 3 урахуванням існуючого рівня розвитку та факторів впливу на формування перспективного потенціал.

\section{Література}

1. Кужилева О. Комплексная оценка инновационного потенциала торговой марки предприятия / О. Кужилева // Маркетинговые исследования в Украине. 2008. - № 1 (26). - C. 32-35.

2. Grinstein A. Demarketing, Minorities, and National

Attachment / A. Grinstein, U. Nisan // Journal of Marketing. - 2009. - Vol. 73, № 2. - P. 105-122.

3. Bennett A. M. The impact of disparate levels of marketplace inclusion on consumer-brand relationships / A. M. Bennett, R. P. Hill, D. Oleksiuk // Journal of Public

ISSN 2312-0967. Pharmaceutical review. 2015. № 1 
Фармацевтичний менеджмент, маркетинг та логістика

Pharmaceutical management, marketing and logistics

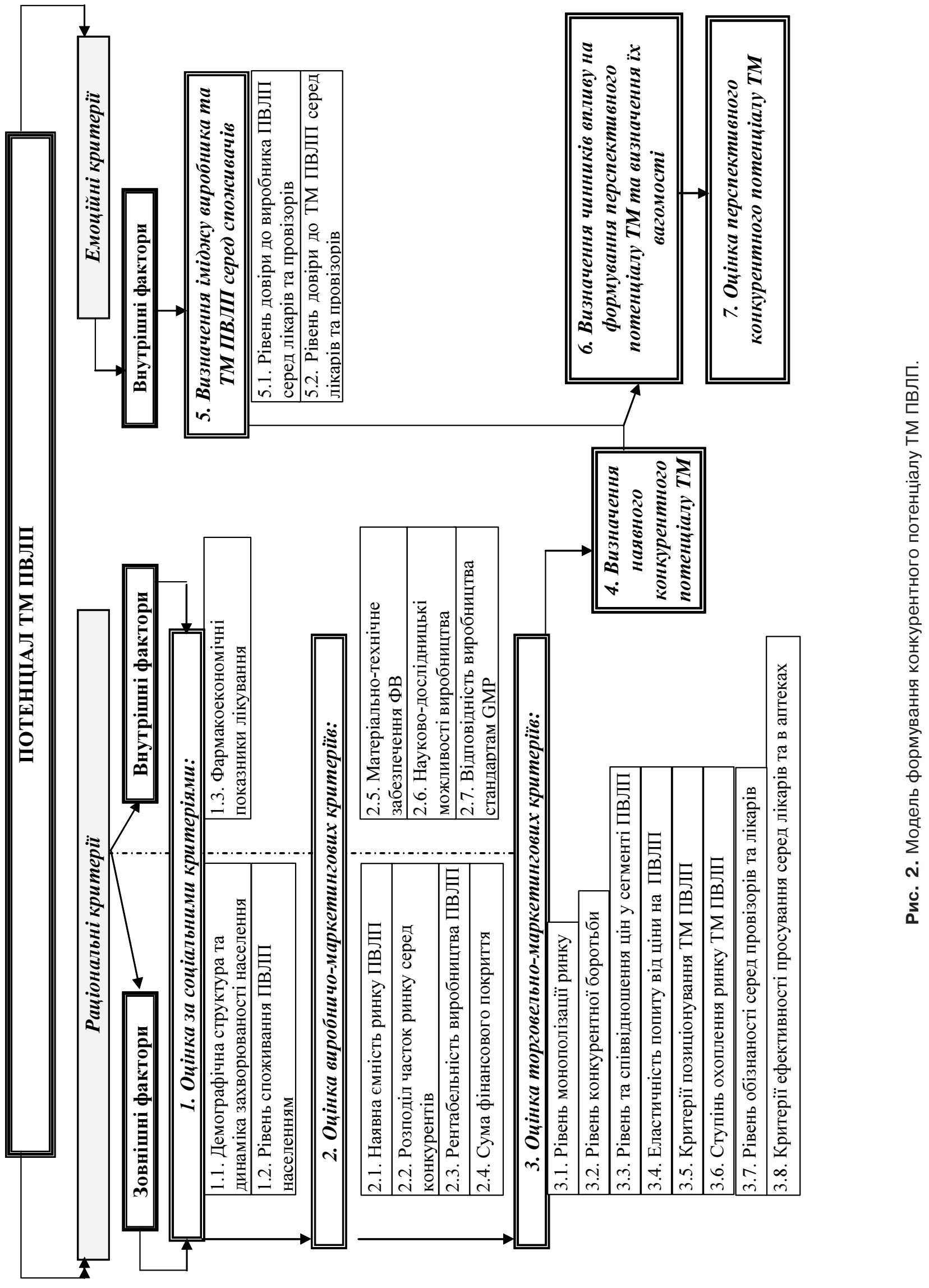

ISSN 2312-0967. Фармацевтичний часопис. 2015. № 1 
Policy \& Marketing. - 2013. - Vol. 32. - P. 16-31.

4. Близнюк С. В. Конкурентний потенціал як категорія сучасних економічних досліджень / С. В. Близнюк, А. В. Остапенко // Інвестиції: практика та досвід. - 2011. - № 7. - C. 40-42.

5. Кривещенко В. Загрози конкурентного середовища у системі економічної безпеки підприємства / В. Кривещенко, М. Єременко // Маркетинг в Україні. - 2014. - № 4. - С. 56-62.

6. Суска А. А. Конкурентный потенциал как категория конкуренции и объект управления / А. А. Суска // Молодой ученый. - 2012. - № 12. - С. 277-279.

7. Толпежникова Р. А. Понятийный апарат экономической категории «конкурентный потенциал предприятия» / Р. А. Толпежникова, А. Р. Ткачева // Теоретичні і практичні аспекти економіки та інтелектуальної власності. - 2014. - Вип. 1 (10), Том 1. С. $143-210$.

8. Родионова Л. Н. Сбалансированность показателей при оценке конкурентоспособности продукции / Л. Н. Родионова, О. Г. Кантор // Экономика региона. 2014. - № 3 - С. 257-265.
Фармацевтичний менеджмент, маркетинг та логістика

Pharmaceutical management, marketing and logistics

9. Ashwin W. Joshi Continuous Supplier Performance Improvement: Effects of Collaborative Communication and Control / W. Joshi Ashwin // Journal of Marketing. - 2009. - Vol. 73, № 1. - P. 133-150.

10. Milne G. R. Toward a Framework for Assessing Covert Marketing Practices / G. R. Milne, S. Bahl, A. Rohm // Journal of Public Policy \& Marketing. - 2008. - Vol. 27, № 1. - Р. 57-62.

11. Слободянюк М. М. Методика оцінки стратегічного ринкового розвитку торговельних марок лікарських препаратів : метод. рек. / М. М. Слободянюк, А. В. Івченко. - Х. : НФаУ, 2009. - 24 с.

12. Слободянюк М. М. Оцінка потенціалу торговельних марок противиразкових лікарських препаратів / М. М. Слободянюк, А. В. Івченко // Запорожский медичний журнал. - 2009. - Т. 11, № 2. - С. 112-115. 13. Котвицкая А. А. Изучение тенденций развития рынка лекарственных препаратов для лечения язвенной болезни желудка в Украине / А. А. Котвицкая, В. П. Ходаковская // Вестник Таджикского национального университета. Серия естественных наук. - 2014. - № 1/3 (134). - C. 181-186.

\section{ПОДХОДЫ К ФОРМИРОВАНИЮ КОНКУРЕНТНОГО ПОТЕНЦИАЛА ТОРГОВЫХ МАРОК НА ПРИМЕРЕ ПРОТИВОЯЗВЕННЫХ ПРЕПАРАТОВ}

\section{А. В. Волкова}

Национальный фармацевтический университет, Харьков

Резюме: проведено обобщение основных подходов к определению понятий «конкурентоспособность», «конкурентный потенциал» и систематизация показателей оценки конкурентоспособности товаров.

Установлено, что на формирование конкурентного потенциала торговых марок влияют рациональные и эмоциональные критерии, оценка которых предполагает проведение комплексного маркетингового и фармакоэкономического анализа лекарственных препаратов. На примере торговых марок группы противоязвенных препаратов обоснована разработанная модель формирования конкурентного потенциала с учетом существующего уровня развития и факторов влияния на формирование перспективного потенциала.

Ключевые слова: конкурентный потенциал, торговые марки, противоязвенные лекарственные препараты.

\section{APPROACHES TO THE FORMATION OF COMPETITIVE TRADEMARK BUILDING ON THE EXAMPLE OF MEDICINES FOR PEPTIC ULCER}

\section{A. V. Volkova}

National University of pharmacy, Kharkiv

Summary: synthesis of the main approaches to definition of the concepts "competitiveness", "competitive potential" and systematization of indicators of an assessment of competitiveness of goods was carried out.

It was found that the formation of the competitive potential of trademarks affect the rational and emotional criteria, the assessment of which involves a comprehensive marketing and pharmacoeconomic analysis of medicines. On the example of trademarks group medicines for peptic ulcer proved developed model of competitive potential, taking into account the current level of development and the factors influencing the formation of long-term potential.

Key words: competitive potential, trademarks, medicines for peptic ulcer. 